\title{
Is the Market Efficiency Static or Dynamic - Evidence from Colombo Stock Exchange (CSE)
}

\author{
Fernando P. N. D. ${ }^{1}$ and Gunasekara A. L. ${ }^{2}$ \\ Department of Finance \\ Faculty of Commerce and Management Studies, University of Kelaniya. \\ ${ }^{1}$ pndfernando@kln.ac.lk, ${ }^{2}$ asitha.kln.ac@ gmail.com
}

\begin{abstract}
The study tests the weak form efficiency of the Colombo Stock Exchange (CSE) and the consistency of the market efficiency concept. In this study, daily market closing index values of (All Share Price Index) ASPI of CSE for five years, from June 2010 to June 2015, without adjustments, have been selected as the sample. Both parametric tests and non-parametric tests have been used and the evidence presented in this study confirms that CSE is not weak form efficient within the sample period going in line with the findings of previous studies. Therefore, the fact that Efficient Market Hypothesis as a dynamic concept is debatable as studies over the past have consistently confirmed that CSE is not in weak form efficient, although the efficiency of the most markets is dynamic.
\end{abstract}

Keywords: Colombo Stock Exchange, ASPI, Weak Form Efficiency, Dynamic Concept, Efficient Market Hypothesis.

\section{Introduction}

Efficiency of the capital markets is a decisive factor for long term investors. A market in which prices always "fully reflect" available information is called "efficient" (Fama, 1970). To be absolutely correct, this is referred to as informationally efficient markets. Therefore, in an efficient capital markets nobody can enjoy abnormal returns using available information as all the available information has already been utilized and reflected in the formation of the current market price.

It is important to test the weak form efficiency in stock markets before testing them for semistrong form or strong form. Because, a market cannot be a one with higher level of efficiency

\footnotetext{
${ }^{2}$ https://orcid.org/0000-0003-3017-8857
} 
without passing the weak form efficiency test. On the other hand, a strong form efficiency market inevitably has the both semi-strong form efficiency and weak form efficiency. Accordingly, this research is focused on testing the weak form efficiency of CSE to create a debate on dynamic market efficiency concept related with the stock market.

Two methods, Technical Analysis and Fundamental Analysis, are basically used to predict/forecast the future prices based on available information. Technical Analysis is the most relevant method when it comes to weak form of market efficiency as it focuses on predicting the future price changes based on historical information. In accordance with Efficient Market Hypothesis theory, market is not efficient if the future price changes can be predicted using any of these methods.

In accordance with the empirical evidence presented in Sensoy and Tabak (2016), the studies using a data set from pre-2008 financial crisis, global emerging markets have become less inefficient in time. Further, inefficient markets become efficient across time with arbitraging market anomalies away with the support of sufficient cash flows (Akbas, Armstrong, Sorescu and Subrahmanyam, 2014) confirming that market efficiency is a dynamic concept. Thus, this study aims at debating the Dynamic Market Efficiency concept presenting challenging evidence from Colombo Stock Exchange.

Apart from that, the findings of this study will confirm whether Technical Analysis methods are useful for making abnormal returns in CSE. Finally, the findings of this study will provide guidance for the future researchers in selecting what level of efficiency to test on CSE. It is a limitation of this study that the (All Share Price Index) ASPI has not been adjusted for thin trading and in this study the transaction cost has not been included. The ASPI index figures taken for the study have not also been adjusted either for scrip or cash dividends.

\section{Review of Literature}

In 1970, the Original idea of Efficient Market Hypothesis (EMH) was fully formulated by Eugene Fama. His influential paper "Efficient Capital Markets: A review of Theory and Empirical Work" presented that the prices in efficient markets fully reflect all available information. In accordance with empirical studies, in an efficient market, successive price changes are independently and identically distributed. This is known as Random Walk Model (RWM). If prices (returns) follow random walk, they should not be serially correlated. 
Fama (1991) revised his work on the weak form efficient hypothesis and covered more general areas instead of only testing the past returns. The new revised weak form efficient hypothesis was named as "Test for Return Predictability".

\section{Previous Studies}

According to Fama (1970), efficient market hypothesis (EMH) can be categorized into three levels based on the definition of the available information set, namely weak form, semi-strong form, and the strong form. The weak form of EMH is the lowest form of efficiency in which the information set is just historical prices. Accordingly, a weak form market is efficient if current prices fully reflect all the available historical price information. This form suggests that past prices cannot be used as a forecasting tool for future stock price fluctuations. Therefore, nobody can make abnormal returns by using only the past history of prices.

Most of the tests that tested the Asian Stock Markets have concluded negatively rather than become favourable on the market efficiency.

Nisar and Hanif (2012) examined the weak form of efficient market hypothesis on the four major stock exchanges of South Asia - India, Pakistan, Bangladesh and Sri Lanka - using historical index values on daily, weekly and monthly basis for a period of 14 years (1997-2011) and have applied four statistical tests, for log returns, including Runs Test, Durbin-Watson Test, Unit Root Test and Variance Ratio Test to test the efficiency. The findings have suggested that all these markets are not in weak form of efficient.

A test by Gilani, Nawaz, Shakoor and Asab (2014) studied the weak form efficiency of Islamabad Stock Exchange (ISE) employing Runs Test, Unit Root Test and Autocorrelation Test in which Runs Test and Autocorrelation Test showed that the market is not efficient at specific periods but Unit Root Test descriptive showed market efficiency in weak form.

The fact that the market efficiency changes over time become evident with the results of the following studies which tested the efficiency of Indian Capital Markets.

Venkatesan (2010) tested Indian National Stock Exchange (NSE) for random walk hypothesis, taking a sample of daily closing price returns of S\&P CNX Nifty from $1^{\text {st }}$ January 2008 to $31^{\text {st }}$ December 2009, using Phillips-Perron Test in addition to Runs Test, Durbin-Watson Test and Unit Root Test. The results of the study revealed the NSE is efficient and supports the Random Walk Behavior. 
However, the test of Shafi (2014) of the weak form efficiency of NSE, taking daily log returns of S\&P CNX Nifty for 11 years from $1^{\text {st }}$ January 2003 to $31^{\text {st }}$ December 2013, using Runs Test, Statistical Tests (Autocorrelation and Descriptive Statistics), Unit Root Test and Kolmogorov Smirov One Sample Test, concluded that the NSE is not efficient in weak form.

The previous studies which tested the market efficiency of Colombo Stock Exchange (CSE) have concluded negatively, being unfavorable on the market efficiency.

Abeyratne and Power (1995) examined the weak form efficiency of CSE with a series of price changes of a period of 16 months for a sample of 20 shares quoted on the CSE from April 1993 to July 1994, utilizing Serial Correlation Analysis and Run Tests and they did not categorically concluded that the CSE is weak form efficient stating that the study is a short time span one and further suggested for future researchers to study for a longer period employing advance methodologies.

Hasan, Samarakoon and Hasan (1999) analysed the price behavior of stocks listed in CSE using daily closing prices of two indices, ASPI and Sensitive Price Index (SPI) over the period January 1985 through December 1995 using Serial Correlation Test, Runs Test, Unit Root Test and Kolmogorov-Smirnov Test. The results of the study suggested that the consecutive changes in stock index values are not random confirming that CSE is not weak from efficient within the sample period.

Abeysekara (2001) examined the market efficiency of Colombo Stock Exchange using daily, weekly and monthly returns of stock indices for the period January 1991 through November 1996 using Serial Correlation Test, Runs Test, Unit Root Test and Test for Security and Portfolio Return Patterns. Results of this study confirmed that the CSE is not weak from efficient providing further evidence that emerging stock markets are not as informationally efficient as developed markets.

Samarakoon (2004) investigated autocorrelations of CSE and industry returns in both shortand long-term holding periods using the major market index, ASPI, and 16 industry indices for the period January 1985 to June 2003. The study concluded that in daily and monthly the market and industry returns show significant autocorrelations providing evidence that returns are predictable from past returns confirming that CSE is predictable and inefficient in the sense of weak form market efficiency. 
Samaratunga (2009) analysed the stock market efficiency of eight economies in Asia-Pacific region including Sri Lanka, using both parametric and non-parametric tests. The data sample period for these economies varies depending on the availability of that country's index but the ending date is $16^{\text {th }}$ May 2008. The results revealed that return predictability exists in CSE and the market is not weak form efficient.

Pathirawasam and Idirisinghe (2011) examined the weak form efficiency of the CSE employing Breusch-Godfrey (BG) test of higher order autocorrelation, taking into account the thin trading, non-linearity and structural changes. The study period is from January 1990 to December 2009. The study found that for the unadjusted returns for thin trading, stock returns are predictable based on past returns. Further, the study concludes that the inefficiency observed at CSE during the sample period is manifested through non-linear behaviour of stock returns.

Fernando (2012) examined the weak form efficiency of emerging Colombo Stock Exchange with both statistical independence tests and technical trading strategies with a sample of daily market closing prices of All Share Price Index (ASPI) for twenty five years from January 1985 to December 2010. The study has employed Autocorrelation Test and Run Test as statistical independence tests and have concluded that the CSE is not weak form efficient, rejecting the null hypothesis.

Table 01: Summary of Research on Testing the Weak Form of Efficiency of CSE

\begin{tabular}{|l|l|l|}
\hline \multicolumn{1}{|c|}{ Author(s) } & Sample Period & \multicolumn{1}{c|}{ Result } \\
\hline $\begin{array}{l}\text { Abeyratne and Power } \\
\text { (1995) }\end{array}$ & $\begin{array}{l}\text { April 1993 to } \\
\text { July 1994 }\end{array}$ & $\begin{array}{l}\text { Not categorically con- } \\
\text { cluded that CSE is } \\
\text { weak form efficient }\end{array}$ \\
\hline $\begin{array}{l}\text { Hasan, Samarakoon } \\
\text { and Hasan (1999) }\end{array}$ & $\begin{array}{l}\text { January 1985 to } \\
\text { December 1995 }\end{array}$ & $\begin{array}{l}\text { CSE is not weak form } \\
\text { efficient }\end{array}$ \\
\hline Abeysekara (2001) & $\begin{array}{l}\text { January 1991 to } \\
\text { November 1996 }\end{array}$ & $\begin{array}{l}\text { CSE is not weak form } \\
\text { efficient }\end{array}$ \\
\hline Samarakoon (2004) & $\begin{array}{l}\text { January 1985 to } \\
\text { June 2003 }\end{array}$ & $\begin{array}{l}\text { CSE is not weak form } \\
\text { efficient }\end{array}$ \\
\hline Samaratunga (2009) & $\begin{array}{l}\text { January 1985 to } \\
\text { May 2008 }\end{array}$ & $\begin{array}{l}\text { CSE is not weak form } \\
\text { efficient }\end{array}$ \\
\hline $\begin{array}{l}\text { Pathirawasam and Id- } \\
\text { irisinghe (2011) }\end{array}$ & $\begin{array}{l}\text { January 1990 to } \\
\text { December 2009 }\end{array}$ & $\begin{array}{l}\text { CSE is not weak form } \\
\text { efficient }\end{array}$ \\
\hline Fernando (2012) & $\begin{array}{l}\text { January 1985 to } \\
\text { December 2010 }\end{array}$ & $\begin{array}{l}\text { CSE is not weak form } \\
\text { efficient }\end{array}$ \\
\hline \multicolumn{2}{|l|}{ Source: Authors Compiled } \\
\hline
\end{tabular}

Source: Authors Compiled 


\section{Hypotheses}

$\mathrm{H} 1$ : The return series is not random.

$\mathrm{H} 2$ : The CSE is not efficient in weak form.

\section{Research Methodology}

The data collection is limited to secondary data sources and only depends on ASPI of CSE. Daily market closing index values of ASPI of CSE for five years, from June 2010 to June 2015 without adjustments, have been selected as the sample, taking the uncovered period by research, to test the latest level of efficiency of CSE.

Two major statistical tests of independence have been employed to verify that security returns over time are independent of one another. The first test is Autocorrelation Tests of independence which measures the significance of positive or negative correlation in returns over time. Further, the following equation can be used to conduct significance tests to check whether the Autocorrelation coefficients are significantly different from zero by constructing a non-rejection area with a $95 \%$ confidence interval.

$$
\pm 1.96 \times \frac{1}{\sqrt{T}}
$$

Here $T$ is the sample size. Accordingly, if the Autocorrelation coefficients fall outside this region for a given lag, the fact that the Autocorrelation coefficient is zero can be rejected.

Ljung-Box Q statistic which is one of the most commonly used tests in recent years as a parametric test to test the Autocorrelation, is also used in this study.

The second test is the Runs Test which is a nonparametric test and will detect the statistical dependencies that may not detect by Autocorrelation. Augmented-Dickey-Fuller (ADF) test is used as a Unit Root Test to test the stationarity of the data series. Instead, Descriptive Statistics will be considered to test whether the given data is normally distributed or not. The EViews software and Microsoft Excel are used to process the data using these statistical models.

The daily ASPI closing values are used to calculate the daily returns using the following log return formula.

$$
\mathrm{R}=\operatorname{Ln}\left(\mathrm{P}_{\mathrm{t}} / \mathrm{P}_{\mathrm{t}-1}\right)
$$


Where,

$\mathrm{R}=$ Daily return

Ln $\quad=$ Natural Log

$\mathrm{P}_{\mathrm{t}} \quad=$ Index at time $\mathrm{t}$

$\mathrm{P}_{\mathrm{t}-1} \quad=$ Index at time $\mathrm{t}-1$

\section{Findings and Discussion}

\section{Descriptive Statistics}

Table 02: Descriptive Statistics

\begin{tabular}{|c|c|}
\hline Sample: & $01 / 06 / 2010-30 / 06 / 2015$ \\
\hline Observations: & 1222 \\
\hline Mean: & 0.000409 \\
\hline Median: & 0.000247 \\
\hline Skewness: & 0.114156 \\
\hline Kurtosis & 7.399661 \\
\hline Jarque-Bera & 988.2491 \\
\hline Probability & 0.000000 \\
\hline
\end{tabular}

Source: Authors Compiled

In accordance with the table, Skewness of the returns distribution is positive or skewed to right. Kurtosis value is also larger than three (3) indicating the distribution is not normally distributed. The Jarque-Bera statistic has a significant $p$ value therefore; we can conclude that the daily returns series of Colombo Stock Exchange is not normally distributed.

\section{Unit Root Test}

Non-stationary data cannot be modeled or used for forecasts because they do not clearly show the real causes for the effect under consideration independent of time. In accordance with the ADF unit root test, the ASPI daily closing price series is not stationary. Thus, the return series or the first difference of ASPI daily closing prices was tested for stationarity. 
Table 02 below shows the results of ADF unit root test performed considering the first difference of the ASPI index series including both the trend and the intercept and using 22 lags for the whole sample period.

Table 03: ADF Unit Root Test for ASPI Index-First Difference

\begin{tabular}{|lccc|}
\hline & & t-Statistic & P-Value \\
\hline Augmented Dickey-Fuller test statistic & -28.22143 & 0.0000 \\
\hline Test critical values: & $1 \%$ level & -3.965580 & \\
& $5 \%$ level & -3.413496 & \\
& $10 \%$ level & -3.128793 & \\
\hline
\end{tabular}

Source: Authors Compiled

In accordance with the above table, the t-Statistic, in absolute terms, is greater than all the critical values at $1 \%, 5 \%$ and $10 \%$ significant levels with a zero P-value. Therefore, in this case, the fact that ASPI index series is non-stationary can be rejected at all 1\%, 5\% and 10\% significant levels. In other words, the ASPI index series is stationary in first difference. Therefore, the return series of ASPI for the sample period can be used for testing the Autocorrelation of the same series.

\section{Autocorrelation Test}

Table 04: Autocorrelation Test

\begin{tabular}{|c|c|c|c|c|c|c|}
\hline \multirow{2}{*}{ Lag } & AC & Q-Stat & Prob. & $\begin{array}{c}\text { Non-Rejection Region } \\
(\mathbf{9 5 \%} \text { Conf. Interval) }\end{array}$ & \multicolumn{2}{|c|}{ Chi-Square } \\
\hline 1 & 0.213 & 55.629 & 0.000 & \pm 0.0561 & $\mathbf{5 \%}$ \\
\hline 2 & 0.069 & 61.482 & 0.000 & \pm 0.0561 & 9.63 & 3.84 \\
\hline 3 & 0.065 & 66.720 & 0.000 & \pm 0.0561 & 11.34 & 7.81 \\
\hline 4 & 0.070 & 72.752 & 0.000 & \pm 0.0561 & 13.28 & 9.49 \\
\hline 5 & 0.044 & 75.140 & 0.000 & \pm 0.0561 & 15.09 & 11.07 \\
\hline
\end{tabular}

Source: Authors Compiled

In accordance with the findings, the Autocorrelation coefficients at lag 1, 2, 3, and 4 fall outside the non-rejection region. Hence, the Autocorrelation coefficient is significantly different from zero and we can reject the fact that Autocorrelation coefficients are zero. Therefore, the return 
of the Colombo Stock Exchange can be predicted using its past information. This indicates that the Colombo Stock Exchange is not in weak form of efficient.

In accordance with the Ljung-Box Q-Statistics, all the Autocorrelation coefficients are jointly significant at all lags at 1\% and 5\% significant levels as all the Q-Statistics are greater than the Chi-Squared values. Therefore, Ljung-Box Q-Statistics confirms that the return series is neither random nor independently and identically distributed. Hence, Colombo Stock Exchange is not efficient in weak form.

\section{Runs Test}

The results of the Runs Test for daily return series of Colombo Stock Exchange for the sample period are presented in the Table 04 below.

Table 05: Runs Test

\begin{tabular}{|l|c|}
\hline Number of Observations & 1,222 \\
\hline Number above Cutoff & 600 \\
\hline Number below Cutoff & 622 \\
\hline Number of Runs & 500 \\
\hline & \multicolumn{2}{|l|}{} \\
\hline E(R) & 611.802 \\
\hline$\sigma$ & 17.466 \\
\hline Z-value & -6.401 \\
\hline Prob. & 0.000 \\
\hline
\end{tabular}

Source: Authors Compiled

In accordance with the above table, the observed number of runs is lesser than the expected number of runs. This confirms that the return series is not random. The critical value of $\mathrm{Z}$ at $5 \%$ significant level is \pm 1.96 (Chung, 2006). The $\mathrm{Z}$ value falls outside the \pm 1.96 region indicating that the return series is not behave in a random fashion. Further, negative $\mathrm{Z}$ value indicates a positive serial correlation going in line with the results of the Autocorrelation Test. In accordance with the above results it can be stated that the Colombo Stock Exchange is not efficient in weak form. 


\section{Conclusion}

This study examines the weak form efficiency of CSE using both parametric and non-parametric tests. The results of Autocorrelation Test and Runs Test are consistent with Fernando (2012) study indicating a positive Serial Correlation. Abeysekara (2001) and Samarakoon (2004) also revealed that daily stock returns of CSE are positively correlated. Thus, market predictability exists in CSE confirming the market is not weak form efficient within the sample period. This also indicates that the excess returns can be generated utilizing investment strategies based on historical data. Therefore, Technical Analysis techniques are valid for CSE and can be utilized to generate excess returns. However, in practice an abnormal return is questionable due to the existence of the transaction cost and this study does not take transaction cost into consideration and it is a limitation of this study.

In accordance with the previous work done by different authors using different tests, the CSE is continuously providing evidence against the weak form efficiency over 30 years, from the beginning (1985) to 2015. Generally, a weak form inefficient market becomes efficient over time with arbitraging away the anomalies. Therefore, the fact that Efficient Market Hypothesis is a dynamic concept is debatable as studies over past have consistently confirmed that CSE is not weak form efficient. One reason for this situation can be the absence of an efficient mechanism to flow the research knowledge to the investors and traders in the Colombo Stock Exchange preventing a healthy arbitrage capital inflow that is sufficient to arbitraging away the anomalies. Therefore, it can be recommended policy makers to take necessary steps to build an efficient mechanism that makes investors and trades aware of the new research knowledge related with the local capital market.

It can be suggested that for future researches to test the weak form of efficiency considering the transaction cost and dividends. Further, different time frequencies such as weekly, monthly returns can be considered for future studies. 
DOI: http://doi.org/10.4038/kjm.v7i1.7551

\section{References}

Abeyratne, G. \& Power, D.M. (1995). A test of the weak-form of the efficient market hypothesis: Evidence using daily data from the Colombo Stock Exchange. Sri Lanka Journal of Social Sciences, 18, 41-53.

Abeysekara, S. P. (2001). Efficient Market Hypothesis and the Emerging Capital Market in Sri Lanka: Evidence from the Colombo Stock Exchange - A Note. Journal of Business Finance and Accounting, 28, 249 - 261 https://doi.org/10.1111/1468-5957.00373

Akbas, F. Armstrong, W. J. Sorescu S. \& Subrahmanyam, A. (2014) Capital Market Efficiency and Arbitrage Efficacy. Retrived from: https://ssrn.com/abstract=2022485 or http://dx.doi.org/10.2139/ssrn.2022485 https://doi.org/10.2139/ssrn.2022485

Arulvel, K.K., Balaputhiran, S., Ramesh, S. \& Nimalathasan, B. (2011). Market Efficiency or Not: A Study of Emerging Market of Colombo Stock Exchange (CSE) in Sri Lank. Retrieved from: http://www.researchgate.net/publication/216521287_ Market_Efficiency_or_NotA_Study_of_Emerging_Market_of_Colombo_Stock_Exchange (CSE)_in_Sri_Lanka.

Brooks, C. (2008): Introductory econometrics for finance. Second Edition. Retrieved from: http://rum.prf.jcu.cz/public/mecirova/eng_ekonomka/Chris_Brooks_Introductory_ Econometrics_for_Fina.pdf. https://doi.org/10.1017/CBO9780511841644

Chung, H. Y. (2006), Testing Weak-Form Efficiency of the Chinese Stock Market, Karhula, China. Department of Business Administration, Lappeenranta University of Technology.

Dailymirror. (2014, October 3). All set for sri lanka's second int'l capital market conference. Dailymirror. Retrieved from: http://www.dailymirror.lk.

Fama, E.F. (1965), The behavior of stock-market prices. The Journal of Business, 38 (1), 3441. https://doi.org/10.1086/294743

Fama, E.F. (1970). Efficient capital markets: A review of theory and empirical work. Journal of Finance, 25 (2), 383-395. https://doi.org/10.2307/2325486 
Fama, E. F. (1991). Efficient capital markets: II. The journal of finance, 46(5), 1575-1617. https://doi.org/10.1111/j.1540-6261.1991.tb04636.x

Fama, E. and French, K. R. (1992). "The Cross Section of Expected Stock Returns,” Journal of Finance 47, no. 2. 427-465. https://doi.org/10.1111/j.1540-6261.1992.tb04398.x

Fernando, P.N.D. (2012). Testing the weak form efficiency of emerging Colombo stock exchange (CSE) with statistical independence tests and technical trading strategies, ZENITH International Journal of Business Economics \& Management Research, 2(4).pp 113.

Gilani, S.T.R., Nawaz, M., Shakoor, M.I., \& Asab, M.Z. (2014). Testing The Weak Form Efficiency of Islamabad Stock Exchange (ISE), Developing Country Studies, ISSN 2224607X (Paper) ISSN 2225-0565 (Online), 4(11).

Guo, S. and Z. Wang (2007). Market efficiency anomalies: A study of seasonality effect on the Chinese stock exchange. Retrieved from: http://www.diva-portal.org/smash/ get/diva2:141436/FULLTEXT01.pdf.

Gupta, R., \& Yang, J. (2011). Testing Weak form Efficiency in the Indian Capital Market. International Research Journal of Finance and Economics. ISSN 1450-2887 Issue 75. 108-119.

Hamid, K., Suleman, T.M., Shah, Z.A.S., \& Akash, R.S.I. (2010). Testing the Weak form of Efficient Market Hypothesis: Empirical Evidence from Asia-Pacific Markets, International Journal of Finance and Economics, ISSN 1450-2887 Issue 58.

Hasan, T., Samarakoon, L. P., \& Hasan, S. (1999). Stock Price Behavior in a Less Developed Market: Evidence from Sri Lanka. Journal of Applied Business Research, Vol. 16, No. 02 , pp. $15-23$.

Lo, A.W. (2007). Efficient Markets Hypothesis. The New Palgrave: A Dictionary of Economics, L. Blume, S. Durlauf, eds., 2nd Edition, Palgrave Macmillan Ltd.

Mobarek, A., \& Keasey, K. (2000). Weak-Form Market Efficiency of An Emerging Market: Evidence from Dhaka Stock Market of Bangladesh, paper presented at the ENBS Conference held on Oslo. 
DOI: http://doi.org/10.4038/kjm.v7i1.7551

Nasdaq Baltic Financial Reports. (2012). Testing Weak-Form Market Efficiency of Developing Markets: Evidence from the Baltic Stock Exchange. Retrieved from: www.nasdaqomxbaltic.com/files/riga/Studiju_darbi/2012/Dissertation-Ieva\%20 Sarkauskyte.pdf.

Nisar, S., \& Hanif, M. (2012). Testing Weak Form of Efficient Market Hypothesis: Empirical Evidence from South-Asia. World Applied Sciences Journal 17:4, 414-427.

Pathirawasam, C., \& Idirisinghe, I M. (2011). Market efficiency, thin trading and non-linear behaviour: Emerging market evidence from Sri Lanka. E a M: Ekonomie a Management. 14. 112-122.

Reilly, F., \& Brown, K. (2011). Investment analysis and portfolio management. Cengage Learning.

Samarakoon, L. P. (2004). Efficiency of the Sri Lankan Stock Market. Sri Lankan Journal of Business Economics, Vol. 1, pp. 1-22.

Samaratunga, D., (2009). Stock Market Efficiency and Integration: A Study of Eight Economies in the Asia-Pacific Region. Staff Studies. 38(1), pp.95-117. https://doi.org/10.4038/ss.v38i1.1223

Sensoy, A., \& Tabak, B. M. (2016). Dynamic Efficiency of Stock Markets and Exchange Rates. International Review of Financial Analysis, 47, 353-371. https://doi.org/10.1016/j.irfa.2016.06.001

Shafi, M. (2014). Testing of Market Efficiency in The Weak-Form Taking CNX NIFTY As a Benchmark Index: A Study, Researchjournali's Journal of Finance, Vol. 2, No. 2.

Venkatesan, K. (2010), “Testing Random Walk Hypothesis of Indian Stock Market Returns: Evidence from The National Stock Exchange (NSE)", ICBI 2010 - University of Kelaniya, Sri Lanka, pp. 2-11. 